\title{
Mutants of Azotobacter chroococcum Defective in Hydrogenase Activity
}

\author{
By M. G. YATES* AND R. L. ROBSON \\ AFRC Unit of Nitrogen Fixation, University of Sussex, Brighton BN1 9RQ, UK
}

(Received 11 December 1984; revised 5 February 1985)

Three classes of Hup ${ }^{-}$mutants of Azotobacter chroococcum were obtained by $N$-methyl- $N^{\prime}$-nitro$N$-nitrosoguanidine mutagenesis and screening by $\mathrm{H}^{3} \mathrm{H}$ uptake: (1) those with no discernible $\mathrm{H}_{2}$-uptake or $\mathrm{H}_{2}$-evolving activity, (2) those showing no uptake but some $\mathrm{H}_{2}$ production and (3) those leaky for both activities. One mutant strain, MCD-124, expressed hydrogenase activity similar to the solubilized wild-type enzyme in $\mathrm{O}_{2}$ sensitivity, sedimenting behaviour and $\mathrm{pH}$ optimum. All the other mutants were probably mutated in the hydrogenase structural or processing (methylene blue) genes rather than in genes for hydrogenase-linked respiratory proteins. Four mutants chosen from the first category were complemented for hydrogenase activity by conjugation with Escherichia coli carrying plasmid pHU1 containing Rhizobium japonicum hydrogenase genes. A pHU1 transconjugant of strain MCD-124, on the other hand, did not express any additional hydrogenase activity.

\section{INTRODUCTION}

Three main types of hydrogenases exist in micro-organisms: (1) the reversible hydrogenase which acts as an electron sink in anaerobes; (2) the ATP-dependent $\mathrm{H}_{2}$ production by nitrogenase; and (3) the $\mathrm{H}_{2}$-uptake hydrogenase activities (Hup) of $\mathrm{H}_{2}$-oxidizing and $\mathrm{N}_{2}$-fixing bacteria (see Yates \& Walker, 1980). In the latter the uptake hydrogenase can recycle $\mathrm{H}_{2}$ produced by nitrogenase through $\mathrm{H}_{2}$-dependent respiration to produce ATP.

All hydrogenases are iron sulphur proteins (Adams et al., 1981) and uptake hydrogenases are usually membrane-bound. The protein from Azotobacter chroococcum has been partially purified; it was estimated to have a molecular weight of $\sim 60000$ and exhibited a very high ( $>100) \mathrm{H}_{2}$ uptake to $\mathrm{H}_{2}$-evolving activity ratio. It was also $\mathrm{O}_{2}$-sensitive when solubilized (Van der Werf \& Yates, 1978). In these respects it resembles the uptake hydrogenase of Rhizobium japonicum bacteroids (Arp \& Burris, 1979).

Expression of hydrogenase activity in $A$. chroococcum is complex and is affected by $\mathrm{O}_{2}, \mathrm{H}_{2}$ and carbon and nitrogen sources (Partridge et al., 1980; Lee and Wilson, 1943); it also requires nickel (Partridge \& Yates, 1982). In most of these respects it again resembles hydrogenase from $R$. japonicum or $R$. japonicum bacteroids (Maier et al., 1978, 1979; Klucas et al., 1983).

In an attempt to understand the role and possible benefits of hydrogenase in $\mathbf{N}_{\mathbf{2}}$-fixing aerobes we have isolated Hup ${ }^{-}$mutants of $A$. chroococcum. The present paper describes preliminary biochemical and genetic characterization of these mutants.

\section{METHODS}

Organisms and strains. Bacteria are described in Table 1. A. chroococcum MCD-1 is a derivative of a non-gummy variant (MCA-1) of $A$. chroococcum NCIMB 8033 (Robson et al., 1984). A. chroococcum strains were grown routinely on Burk's $\mathrm{N}$-free sucrose medium (Newton et al., 1953) or on rich medium (RM) (Robson et al., 1984) at $30^{\circ} \mathrm{C}$ under air. Tetracycline $\left(5 \mu \mathrm{g} \mathrm{ml}^{-1}\right)$ was added as required. Escherichia coli $\mathrm{HB} 101$ was grown in LuriaBertani (LB) medium containing either tetracycline $\left(10 \mu \mathrm{g} \mathrm{ml}^{-1}\right)$ or kanamycin $\left(15 \mu \mathrm{g} \mathrm{ml}^{-1}\right)$ or both.

Abbreviation: MNNG, $N$-methyl- $N^{\prime}$-nitro- $N$-nitrosoguanidine. 
Table 1. Bacterial strains and plasmids

Strain

Azotobacter chroococcum MCA-1

MCD-1

Escherichia coli

HB101

Plasmids

pRK2013

pHU1
Genotype or phenotype

Reference or source
$\mathrm{Sm}^{\mathrm{r}} \mathrm{Nal}{ }^{\mathrm{r}}$

$\mathrm{F}^{-} h s d-20 r_{\overline{\mathrm{B}}}^{-} m_{\overline{\mathrm{B}}}$ recA13 ara-14 proA 2 lac $Y$ galK2 rpsL20 xyl-5 mtl-1 supE44

$\mathrm{Km}^{\mathrm{r}} \mathrm{Tra}^{+}$. Helper plasmid

$\mathrm{Tc}^{\mathrm{r}} \mathrm{Mob}^{+}$
Robson et al. (1984)

Boyer \& Roullard-Dussoix (1969)

Figurski \& Helinski (1979)

Cantrell et al. (1983)

Plasmid pHU1 (Table 1), which carries some determinants for the uptake hydrogenase from $R$. japonicum in the wide host range vector plasmid pLAFR1 (Cantrell et al., 1983), was a gift from Dr M. A. Cantrell and Professor H. J. Evans of Oregon State University, Corvallis, USA.

Mutagenesis. A. chroococcum MCDl, grown to approximately $10^{8}$ organisms $\mathrm{ml}^{-1}$, was mutagenized with $N$ methyl- $N^{\prime}$-nitro- $N$-nitrosoguanidine (MNNG, $20 \mu \mathrm{g} \mathrm{ml}^{-1}$ ) for $10 \mathrm{~min}$ to a survival of 10 to $50 \%$, collected on sterile cellulose nitrate filter discs (Sartorius), washed with PEM buffer (Robson et al., 1984) to remove MNNG and out-grown on the discs on Burk's sucrose nutrient agar $(4: 1, \mathrm{v} / \mathrm{v})$ containing $0 \cdot 1 \%$ yeast extract (BSYNA) for $24 \mathrm{~h}$. Single colonies obtained on BSYNA $48 \mathrm{~h}$ after serial dilution of bacterial lawns were transferred to Burk's sucrose agar (approx. $0.5 \mathrm{ml}$ ) in Sterilin U-cavity plates and grown for $2 \mathrm{~d}$.

Selection of Hup mutants. Colonies grown on U-cavity plates were exposed for 10 min to $\mathrm{H}^{3} \mathrm{H}+\mathrm{H}_{2}(10 \%, \mathrm{v} / \mathrm{v}$, containing $25.9 \mathrm{MBq} \mathrm{H}^{3} \mathrm{H}$ ) in air ( 3.4 litre) at room temperature. Tritiated protons released into the agar blocks were counted in a Beckman scintillation counter with $20 \%$ LUMAX in toluene as the scintillant. The vials were shaken and equilibrated in the dark for $1 \mathrm{~h}$ before counting.

Hydrogenase assay. $\mathrm{H}_{2}$-uptake activity was measured anaerobically with methylene blue as the electron acceptor essentially as described by Pedrosa et al. (1982), with either $0 \cdot 1 \mathrm{M}$-sodium phosphate buffer, $\mathrm{pH} 8 \cdot 0$, or $0 \cdot 1 \mathrm{M}$-citric acid/sodium phosphate buffer, $\mathrm{pH} 5 \cdot 5$. Other electron acceptors, except $\mathrm{O}_{2}$, were tested at $8 \cdot 2 \mathrm{mM}$ at the $\mathrm{pH}$ optimum of the particulate $\left(\mathrm{pH} \mathrm{8.0)}\right.$ ) or solubilized (pH 5.5) enzyme (Van der Werf \& Yates, 1978). $\mathrm{O}_{2}$ dependent $\mathrm{H}^{3} \mathrm{H}$ uptake was measured in $1 \mathrm{ml}$ culture portions ( $\mathrm{pH} \mathrm{6.5)} \mathrm{in} 8 \mathrm{ml}$ serum bottles sealed with a suba seal under air plus $10 \% \mathrm{H}^{3} \mathrm{H}+\mathrm{H}_{2}$ at $30^{\circ} \mathrm{C}$.

$\mathrm{H}_{2}$ evolved by hydrogenase was measured in crude extracts under anaerobic conditions with sodium dithionite ( $20 \mathrm{mM}$ ) and methyl viologen ( $2 \mathrm{mM}$ ) in $0 \cdot 1 \mathrm{M}$-sodium phosphate buffer, $\mathrm{pH} 6.5$. The $\mathrm{H}_{2}$ produced was measured by gas chromatography on a molecular sieve MS SA column with a thermal conductivity detector (Pye Unicam 204).

Crude extracts for either $\mathrm{H}_{2}$-uptake or $\mathrm{H}_{2}$-evolution measurements were obtained by resuspending bacteria ( $5 \mathrm{ml} ; 2 \mathrm{mg}$ protein $\mathrm{ml}^{-1}$ ) in $0.1 \mathrm{M}$-sodium phosphate buffer, $\mathrm{pH} \mathrm{8.0,} \mathrm{and} \mathrm{disrupting} \mathrm{them} \mathrm{in} \mathrm{an} \mathrm{Aminco} \mathrm{pressure}$ cell from $26 \mathrm{MPa}$. Extracts were stored in liquid nitrogen.

Protein was measured by the Folin reagent with bovine serum albumin as the standard.

DNA analysis by gel electrophoresis. Small scale analysis of plasmids from $E$. coli and $A$. chroococcum was by alkaline lysis followed by electrophoresis on horizontal gels of $0.7 \%(w / v)$ agarose at $4{ }^{\circ} \mathrm{C}$ and $80 \mathrm{~V}$ for $16 \mathrm{~h}$ in TAE buffer (Robson et al., 1984).

Genetic techniques. E. coli $\mathrm{HB101}$ (pHU1) and HB101(pRK2013) were mated overnight at $30^{\circ} \mathrm{C}$ on filter discs on $\mathrm{RM}$ medium agar containing glucose $(0.5 \%, \mathrm{w} / \mathrm{v})$ and $\mathrm{NH}_{4} \mathrm{Cl}(5 \mathrm{mM})$. Transconjugants [E. coli $\mathrm{HB} 101$ (pHU1, pRK 2013)] carrying both plasmids were isolated and maintained on LB containing tetracycline $\left(10 \mu \mathrm{g} \mathrm{ml}^{-1}\right)$ and kanamycin $\left(25 \mu \mathrm{g} \mathrm{ml}^{-1}\right)$.

All salts were purchased from BDH and all biochemicals, electron acceptors, antibiotics and MNNG from Sigma. ${ }^{63} \mathrm{Ni}^{2+}$ and $\mathrm{H}^{3} \mathrm{H}$ were obtained from Amersham.

\section{RESULTS}

Table 2 shows the hydrogenase activities of the parent, $\mathrm{MCD}-1\left(\mathrm{Hup}^{+}\right)$, and strains defective in hydrogenase activity (Hup ${ }^{-}$) obtained after MNNG mutagenesis. Originally, 24 mutants were obtained from 1850 colonies; a frequency of $1.3 \times 10^{-2}$. Eight of these failed to survive after sub-culturing. Of the remaining 16 , the frequency of reversion was less than $5 \times 10^{4}$, the limit of the screening technique for $\mathrm{Hup}^{+}$revertants.

The surviving mutants can be divided into three subgroups on the basis of relative activities (Table 2): (1) those with very low activities in agar blocks ( $<200$ c.p.m.) or in $\mathrm{O}_{2}$ - or methylene blue-dependent $\mathrm{H}_{2}$-uptake assays and with no detectable $\mathrm{H}_{2}$-evolving activity; (2) those with 
Table 2. Hydrogenase activities of parent and Hup ${ }^{-}$mutants of A. chroococcum

Assay procedures are described in Methods. All activities of the mutants represent the highest values obtained from at least two assays.

\begin{tabular}{|c|c|c|c|c|c|c|}
\hline \multirow[b]{3}{*}{ Strain } & \multirow[b]{3}{*}{ Hup } & \multicolumn{3}{|c|}{ Hydrogenase activity $\left(\mathrm{H}^{3} \mathrm{H}+\mathrm{H}_{2}\right.$ uptake) } & \multirow{3}{*}{$\begin{array}{c}\text { Percentage } \\
\mathrm{H}_{2} \text {-evolving } \\
\text { activity }\end{array}$} & \multirow{3}{*}{$\begin{array}{l}\text { Secondary } \\
\text { phenotype }\end{array}$} \\
\hline & & \multirow{2}{*}{$\begin{array}{c}\text { 'U-cavity' } \\
\text { agar } \\
\text { blocks } \\
\text { (c.p.m.)* }\end{array}$} & & $\begin{array}{c}\text { Methylene blue- } \\
\text { dependent } \dagger\end{array}$ & & \\
\hline & & & \multicolumn{2}{|c|}{$\overbrace{\left[\mathrm{nmol} \mathrm{H}_{2}(\mathrm{mg} \text { protein })^{-1} \mathrm{~min}^{-1}\right]}^{\text {aependent }}$} & & \\
\hline MCD-1 & + & 35907 & 228 & 855 & 100 & \\
\hline MCD-105 & - & 185 & 0.3 & 0.6 & 0 & Fast growth \\
\hline MCD-108 & - & 133 & $0 \cdot 1$ & 0.4 & 0 & \\
\hline MCD-1 10 & - & 178 & $0 \cdot 15$ & 0 & 0 & \\
\hline MCD-112 & - & 173 & $0 \cdot 1$ & 0.7 & 0 & Slow growth \\
\hline MCD-115 & - & 211 & 0 & 0.2 & 0 & \\
\hline MCD-116 & - & 288 & 0 & $0 \cdot 1$ & 0 & \\
\hline MCD-117 & - & 175 & $0 \cdot 1$ & 0.4 & 0 & \\
\hline MCD-119 & - & 118 & 0 & 0 & 0 & Acid $^{+}$ \\
\hline MCD-122 & - & 286 & $0 \cdot 2$ & 0 & 0 & \\
\hline MCD-102 & $-\S$ & 209 & 0.7 & 0.4 & 4 & \\
\hline MCD-103 & $-\S$ & 142 & $0 \cdot 1$ & 0 & 3 & \\
\hline MCD-104 & $-\S$ & 197 & 0.2 & 0.7 & 2 & \\
\hline MCD-106 & $-\S$ & 153 & $0 \cdot 1$ & $0 \cdot 2$ & 3 & \\
\hline MCD-113 & $-\|$ & 543 & $6 \cdot 1$ & $3 \cdot 7$ & 2 & \\
\hline MCD-118 & $-\|$ & 300 & $1 \cdot 7$ & 2.9 & 7 & Mb uptake ${ }^{-}$ \\
\hline MCD-124 & $-\|$ & 1056 & 3.0 & $0 \cdot 2$ & 40 & Acid $^{-}$ \\
\hline Blank & & 64 & - & - & 0 & \\
\hline
\end{tabular}

equally low $\mathrm{H}_{2}$-uptake activities but discernible $\mathrm{H}_{2}$ evolution; and (3) those with significant $\mathrm{H}_{2}$ uptake and $\mathrm{H}_{2}$-evolving activities. Because of the high sensitivity of the $\mathrm{H}^{3} \mathrm{H}$-uptake assay it was difficult to decide whether low positive $\mathrm{H}^{3} \mathrm{H}$-uptake values reflected low hydrogenase activity or non-specific absorption by bacteria. Thus emphasis was placed on failure to observe $\mathrm{H}_{2}$-evolving capacity when designating a Hup- strain. Mutant MCD-124 contained a soluble hydrogenase with optimal methylene blue-dependent $\mathrm{H}_{2}$-uptake activity at $\mathrm{pH} 5 \cdot 5$. This was usually $<10 \%$ of the parent $\mathrm{Hup}^{+}$strain but it varied considerably and in one culture reached $60 \%$ of the wild-type activity.

Secondary phenotypes were observed for some of the mutants. MCD-105 apparently grew more rapidly than the parent strain on Burk's sucrose agar (colonies were more easily discerned after $24 \mathrm{~h}$ ). MCD-112 grew slowly on agar (5 to $6 \mathrm{~d}$ for colonies to become easily visible compared with $2 \mathrm{~d}$ for MCD-1) or in liquid culture. Mutant MCD-119 produced more acid than MCD-1 in N-free Burk's medium; batch cultures of $A$. chroococcum progressively acidify during growth (pH 7.4 to $\mathrm{pH} \mathrm{6.3} \mathrm{in} 2 \mathrm{~d}$ ), while MCD-119 cultures were usually $\mathrm{pH} \mathrm{6.1} \mathrm{at} \mathrm{this} \mathrm{stage.}$ Under similar circumstances cultures of mutant MCD-124, which produced less acid than the parent strain, were pH 6.5 to 6.6. Mutant MCD-118 apparently failed to absorb methylene blue; methylene blue-dependent hydrogenase activity was $15 \%$ of the parent in crude extracts but almost negligible in whole cells.

All the mutants obtained were defective in both $\mathrm{O}_{2-}$ and methylene blue-dependent hydrogenase activity, indicating that the mutations were probably in the hydrogenase genes rather than any other gene coding for proteins involved in a hydrogenase-linked respiratory chain. A possible exception, mutant MCD-124, is discussed below. 


\section{Table 3. Reactions of hydrogenases from A. chroococcum with electron acceptors}

Assay conditions are described in Methods. Crude supernatants from Burk's sucrose grown cells were used (mg protein per assay: MCD-1, 0.22; MCD-124, 0.24). The electron acceptors were used at a final concentration of $8.2 \mathrm{mM}$. Methyl viologen, phenazine methosulphate and brilliant cresyl blue were dissolved in water, the others in dimethyl sulphoxide (DMSO).

\begin{tabular}{|c|c|c|c|c|}
\hline \multirow[b]{2}{*}{ Electron acceptor } & \multirow[b]{2}{*}{$\begin{array}{l}\text { Redox potential, } \\
\qquad E_{0}(\mathrm{mV})\end{array}$} & \multicolumn{3}{|c|}{ Percentage hydrogenase activity* } \\
\hline & & $\begin{array}{c}\text { MCD-1 } \\
\text { at pH 8.0 }\end{array}$ & $\begin{array}{l}\text { MCD-1 } \\
\text { at } \mathrm{pH} 5 \cdot 5\end{array}$ & $\begin{array}{l}\text { MCD-124 } \\
\text { at pH 5.5 }\end{array}$ \\
\hline Methyl viologen & -339 & ND & 17 & 11 \\
\hline NAD & -320 & ND & 16 & 8 \\
\hline Anthraquinone sulphonic acid & -225 & 6 & 21 & 51 \\
\hline Indigo carmine & -125 & 6 & 20 & 35 \\
\hline Tetrazolium salt & -80 & 7 & 11 & 8 \\
\hline 2,5-Hydroxybenzoquinone & -60 & 10 & 4 & 6 \\
\hline Methylene blue & +11 & 100 & 100 & 100 \\
\hline Methylene blue + DMSO & +11 & 101 & 93 & $62 \pm 15$ \\
\hline Janus green & +41 & 12 & 63 & 10 \\
\hline Brilliant cresyl blue & +48 & 168 & 75 & 18 \\
\hline Thionine & +64 & 73 & 66 & 33 \\
\hline Phenazine-methosulphate & +80 & 27 & 46 & 47 \\
\hline 2,4-Dimethylbenzoquinone & +180 & 51 & 52 & 13 \\
\hline \multicolumn{5}{|c|}{ 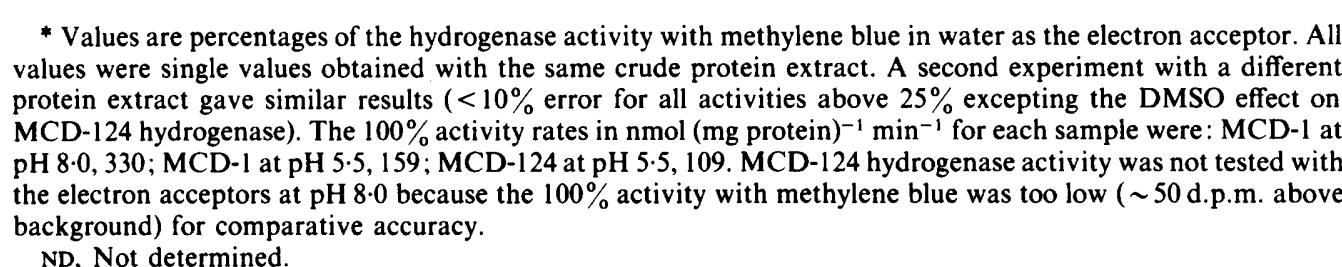 } \\
\hline
\end{tabular}

All the Hup ${ }^{-}$mutants were $\mathrm{Nif}^{+}$; they all grew normally on $\mathrm{N}$-free Burk's sucrose medium and reduced $\mathrm{C}_{2} \mathrm{H}_{2}$ as effectively as the parent with the exception of the slow-growing mutant MCD-112.

Nickel is essential for hydrogenase expression in A. chroococcum (Partridge \& Yates, 1982). However, all the mutants absorbed ${ }^{63} \mathrm{Ni}^{2+}$ as readily as the parent.

Biochemical complementation studies. Maier \& Mutaftschiev (1982) observed that extracts of soybean bacteroids inoculated with two $\mathrm{Hup}^{-}$strains of $R$. japonicum yielded hydrogenase activity when incubated together for several hours. No hydrogenase activity was obtained in similar experiments with $A$. chroococcum Hup $^{-}$mutant extracts mixed in groups, or all together, and incubated anaerobically at $30^{\circ} \mathrm{C}$ and $\mathrm{pH} 7.5$ for $16 \mathrm{~h}$ in the presence of chloramphenicol $(30 \mu \mathrm{g} \mathrm{ml})$.

$\mathrm{H}_{2}$-uptake activity in $\mathrm{MCD}-124$. Hydrogenase activities of MCD-124 varied widely from batch to batch of organisms but were generally lower than those of the parent: 0 to $60 \%$ for methylene blue-dependent $\mathrm{H}_{2}$ uptake and $40 \%$ for $\mathrm{H}_{2}$ evolution. This enzyme differed from the uptake hydrogenase of MCD-1 in the following aspects. (1) It remained (70 to $100 \%$ ) in the supernatant after centrifuging the crude extract at $100000 \mathrm{~g}$ for $90 \mathrm{~min}$ whereas 60 to $100 \%$ of the hydrogenase activity of MCD-1 sedimented under the same conditions. (2) The pH optimum for $\mathrm{H}_{2}$ uptake in crude extracts was $5 \cdot 5$ whereas that of the wild-type was 8.0. (3) It was apparently more sensitive to oxygen; $\mathrm{O}_{2}$-dependent $\mathrm{H}^{3} \mathrm{H}$ uptake was at a maximum below $2 \%(\mathrm{v} / \mathrm{v}) \mathrm{O}_{2}$ in MCD- 124 compared with $40 \%(v / v) \mathrm{O}_{2}$ in MCD-1, although exposure of crude extracts to air for 45 min led to only a slightly greater loss of hydrogenase activity in MCD-124 than in MCD-1 extracts ( 36 and $26 \%$ respectively). (4) Hydrogenase activity in MCD-124 was more sensitive to dimethyl sulphoxide (DMSO) than was that of the wild-type $A$. chroococcum, since $10 \%(\mathrm{v} / \mathrm{v})$ DMSO inhibited hydrogenases in crude extracts from MCD-124 by 23 to $53 \%$ and from MCD-1 by 0 to $7 \%$ at pH 5.5 (Table 3 ). 


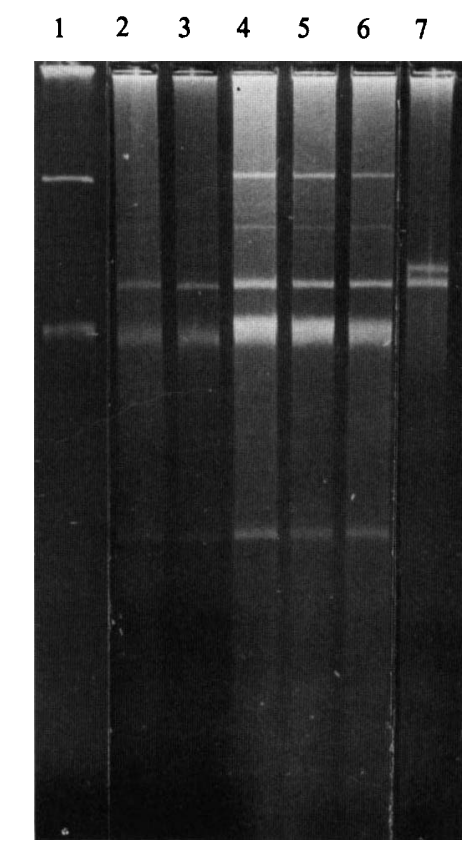

Fig. 1. Agarose gel electrophoresis of plasmids from $A$. chroococcum strain MCD-1, the pHU1 transconjugants of Hup- mutants of $A$. chroococcum and $E$. coli HB101(pHU1, pRK2013). Plasmid isolation and electrophoresis are described in Methods. 1, MCD-1 ; 2, MCD-105(pHU1); 3, MCD115 (pHU1); 4, MCD-117(pHU1); 5, MCD-122(pHU1); 6, MCD-124(pHU1); 7, E. coli HB101(pHU1, pRK2013). pHUl is reported to be $46.9 \mathrm{~kb}$ in length (Haugland et al., 1984).

Other electron acceptors. Table 3 shows how other electron acceptors substituted for methylene blue in the $\mathrm{H}_{2}$-uptake assay with particulate and soluble preparations from $A$. chroococcum MCD-1 and MCD-124 respectively. The best electron acceptors for both hydrogenase preparations were those with mid-point potentials between $+11 \mathrm{mV}$ (methylene blue) and $+80 \mathrm{mV}$ (phenazine methosulphate). There were some major differences between the preparations: indigo carmine $\left(E_{0}-125 \mathrm{mV}\right)$ and anthraquinone sulphonic acid $\left(E_{0}-225 \mathrm{mV}\right)$ were much better electron acceptors for the soluble hydrogenase from MCD-124, despite the presence of DMSO, than for the particulate enzyme. On the other hand, brilliant cresyl blue was a good electron acceptor for the particulate enzyme from MCD-1 at $\mathrm{pH} 8.0$ and 5.5 but not for hydrogenase in MCD-124.

Genetic complementation. Plasmid pHU1, containing determinants for hydrogenase from $R$. japonicum (see Methods), was introduced into Hup- strains of $A$. chroococcum by conjugation with $E$. coli HB101 (pHU1, pRK2013). Transconjugants were shown to contain plasmid pHU1 by agarose gel electrophoresis (Fig. 1). Four Hup ${ }^{-}$strains (MCD-105, 115, 117 and 122) were all restored to $\mathrm{Hup}^{+}$with hydrogenase activity at optimum rates comparable to that of the parent strain, MCD-1 (Table 4). In MCD-124(pHU1), on the other hand, no increased activity was observed at $\mathrm{pH} 5.5$ or 8.0 over that present in MCD-124.

Plasmid patterns. Plasmid patterns in all the $\mathrm{Hup}^{-}$mutants tested were identical to that of the parent MCD-1. This is contrary to the situation in $R$. japonicum where Hup ${ }^{+}$strains contain no discernible plasmids but Hup- strains or mutants do contain plasmids (Cantrell et al., 1983).

\section{DISCUSSION}

Hup $^{-}$mutants of $A$. chroococcum were obtained at an approximate frequency of $10^{-2}$ following exposure to MNNG. This unexpectedly high frequency has several possible explanations. (1) The growth conditions used to outgrow the survivors following mutagenesis 


\section{Table 4. Effect of pHUI on hydrogenase activity of Hup- mutants of A. chroococcum}

Activities were tested with whole cells grown in RM plus antibiotics as described in Methods. The activities of the mutants without plasmids at $\mathrm{pH} 8.0$ are given in Table 2; their activities (excepting MCD-124) at $\mathrm{pH} 5.5$ were zero. The figures in parentheses are from a second growth experiment.

\begin{tabular}{|c|c|c|c|c|c|c|c|}
\hline \multirow[b]{3}{*}{ Strain } & \multirow{3}{*}{$\begin{array}{l}\text { Electron } \\
\text { acceptor }\end{array}$} & \multicolumn{6}{|c|}{$\begin{array}{c}\text { Hydrogenase activity } \\
\left.\left.\text { [nmol } \mathrm{H}^{3} \mathrm{H} \text { absorbed (mg protein }\right)^{-1} \min ^{-1}\right]\end{array}$} \\
\hline & & \multicolumn{4}{|c|}{ Methylene blue } & \multirow{2}{*}{\multicolumn{2}{|c|}{$\mathrm{O}_{2}$}} \\
\hline & & \multicolumn{2}{|c|}{$\mathrm{pH} 8.0$} & \multicolumn{2}{|c|}{ pH $5 \cdot 5$} & & \\
\hline MCD-105(pHU1) & & 144 & (189) & & (87) & 69 & $(102)$ \\
\hline MCD-115(pHU1) & & 207 & (163) & 119 & (90) & 116 & (96) \\
\hline MCD-117(pHU1) & & 379 & (179) & 185 & (94) & 153 & (89) \\
\hline MCD-122(pHUI) & & 339 & (230) & 225 & (142) & 121 & (74) \\
\hline MCD-124(pHUl) & & 3 & (4) & & (14) & 4 & (5.5) \\
\hline MCD-124 & & & $(1 \cdot 3)$ & & (46) & & $(2 \cdot 1)$ \\
\hline MCD-1 (Wild-type) & & 180 & (173) & 165 & (103) & 94 & (61) \\
\hline
\end{tabular}

may have enriched for this phenotype. (2) There are relatively few genes specific for hydrogenase but they were more susceptible to mutagenesis than the bulk of the genome. (3) A substantial number of genes may be required for hup expression. The genome of Azotobacter is approximately $2000 \mathrm{kbp}$ (Robson et al., 1984) and so a frequency of mutagenesis of $1 \% \mathrm{might}$ indicate that in the order of $20 \mathrm{kbp}$ code for genes for hup. Haugland et al. (1984) have reported that $\mathrm{Tn} 5$ insertions which affect hydrogenase activity in the plasmid pHU1 cover a region of at least $15.5 \mathrm{~kb}$, which compares well with the above estimate for $A$. chroococcum. In similar conditions of mutagenesis, presumptive $\mathrm{Nif}^{-}$(nitrogen fixation ${ }^{-}$) mutants are also obtained at a frequency of 1 to $2 \%$ and it can be expected that at least in the order of 17 genes are required for Nif in Azotobacter by analogy with Klebsiella pneumoniae (Jones et al., 1984). (4) hup genes may be plasmid borne as in other organisms (Brewin et al., 1980; Friedrich \& Friedrich, 1983) and MNNG may induce curing of the plasmid at high frequency. This explanation is unlikely because the Hup ${ }^{-}$mutants have the same indigenous plasmid pattern as the parent strain MCD-1. Moreover, when the indigenous plasmids found in A. chroococcum MCA-1 were cured, hydrogenase activity was unaffected (Robson et al., 1984). However, the possibility that hup genes are present on a very large plasmid that is undetected by alkaline lysis cannot be excluded. The hup genes in $R$. japonicum may be on a large undetected plasmid which breaks down to give detectable plasmids and the loss of the Hup ${ }^{+}$phenotype (Cantrell et al., 1982).

Three classes of Hup $^{-}$mutants were designated by this study: those with barely detectable hydrogen uptake and no $\mathrm{H}_{2}$-evolving activity; those with some $\mathrm{H}_{2}$-evolving and little or no $\mathrm{H}_{2}$ uptake activity; those with low but discernible $\mathrm{H}_{2}$-uptake and $\mathrm{H}_{2}$-evolving activity. Whether these categories reflect truly different phenotypes or merely lack of assay sensitivity will be determined by further genetic analysis. However, one mutant, MCD-124, exhibited relatively high, though variable, activities and was shown to contain a largely soluble hydrogenase, whereas the parent strain contained a membrane-bound enzyme. The activity present in MCD124 also differed from the parental enzyme with respect to $\mathrm{O}_{2}$ sensitivity, pH optimum and behaviour with electron acceptors. Preliminary results (M. G. Yates, unpublished) indicate that the partly purified and solubilized hydrogenase from $A$. chroococcum MCA-1 behaves differently from the MCD-124 enzyme with electron acceptors. However, whether this difference reflects the mutation which prevents the enzyme, once synthesized, from binding to the membrane is not known. Alternative possibilities which could cause this phenotype include mutations in other membrane components or processing enzymes.

The wide variation of hydrogenase activity in MCD-124 cannot be explained by $\mathrm{O}_{2}$ sensitivity. Maximum $\mathrm{O}_{2}$-dependent $\mathrm{H}^{3} \mathrm{H}$ uptake occurred at $<2 \%(\mathrm{v} / \mathrm{v}) \mathrm{O}_{2}$ but some $30 \%$ of activity was still left at $50 \%(\mathrm{v} / \mathrm{v}) \mathrm{O}_{2}$; moreover, exposure of crude extracts to air only slowly decreased the activity by $30 \%$ in $45 \mathrm{~min}$. 
The secondary phenotypes (fast and slow growth, high or low acid production and resistance to methylene blue) may be due to secondary mutations, induced by MNNG, which are unrelated to the hup genes, since these differences were confined to few of the Hup ${ }^{-}$mutants. However, MCD-118 (defective for methylene blue uptake) and MCD-124 (soluble hydrogenase and acid-) belong to the third group of mutant types, those with discernible $\mathrm{H}_{2}$-uptake and $\mathrm{H}_{2}$-evolving activity, and these mutations might be pleiotropic. This possibility could be resolved by isolating Hup $^{+}$revertants.

High hydrogenase activity at $\mathrm{pH} 8.0$ compared to that at $\mathrm{pH} 5.5$ indicated that the four plasmid pHU1 transconjugants of MCD-105, 115, 117 and 122 contained particulate hydrogenase. This suggests that $R$. japonicum hydrogenase, which also has a $\mathrm{pH}$ optimum at pH 8.0, is so similar to $A$. chroococcum hydrogenase that it is incorporated into Azotobacter membranes. However, by its failure to complement MCD-124, plasmid pHU1 either does not contain genes for processing hydrogenase into the membranes or, if present, they will not operate in $A$. chroococcum. On the other hand, the fact that pHU1 did not increase the soluble hydrogenase activity in MCD-124 suggests that either $R$. japonicum hydrogenase was very unstable when soluble in vivo or, alternatively, that it was not synthesized by pHU1 in MCD-124. This leads to the alternative possibility that pHU1 carries $R$. japonicum hup regulatory genes whose products activate $A$. chroococcum hup promoters. The hup genes apparently span at least $15.5 \mathrm{~kb}$ in this plasmid (Haugland et al., 1984) but it seems not to contain all the genes necessary for hup expression (Cantrell et al., 1983). MCD-104, 115, 117 and 122 could be regulatory Hupmutants of $A$. chroococcum. This possibility must await further characterization of plasmid pHUl or hup clones from $A$. chroococcum.

Some organisms contain more than one hydrogenase, e.g. Alcaligenes eutrophus (Schink \& Schlegel, 1978), Clostridium pasteurianum (Chen \& Blanchard, 1984; Adams \& Mortenson, 1984) and E. coli (Ballantine \& Boxer, 1985). Ackrell et al. (1966) found that Azotobacter vinelandii contained several hydrogenase fractions, but these may not have contained different hydrogenase proteins. Zero hydrogenase activity in several Hup ${ }^{-}$mutants of $A$. chroococcum suggests that either only one hydrogenase exists in this organism or if more than one is present they may have common genetic determinants.

We wish to thank Professor Harold Evans and Dr M. A. Cantrell for the plasmid pHU1, Professor J. R. Postgate and Drs Christina Kennedy and Aresa Toukdarian for useful discussion and Frances Campbell for technical assistance.

\section{REFERENCES}

ACkrell, B. A. C., Asato, R. N. \& Mower, H. F (1966). Multiple forms of bacterial hydrogenases. Journal of Bacteriology 92, 828-838.

Adams, M. W. \& Mortenson, L. E. (1984). The physical and catalytic properties of hydrogenase 2 of Clostridium pasteurianum. A comparison with hydrogenase 1. Journal of Biological Chemistry 259, 7045 7055 .

Adams, M. W., Mortenson, L. E. \& Chen, J.-S. (1981). Hydrogenase. Biochimica et biophysica acta 594, 105-176.

ARP, D. J. \& BURris, R. H. (1979). Purification and properties of the particulate hydrogenase from the bacteroids of soybean nodules. Biochimica et biophysica acta 570, 221-230.

Ballantine, S. P. \& Boxer, D. H. (1985). Nickelcontaining hydrogenase isoenzymes from anaerobically grown Escherichia coli K 12. Journal of Bacteriology (in the Press).

BOYER, H. B. \& Roullard-Dussoix, D. (1969). A complementation analysis of the restriction and modification of DNA in Escherichia coli. Journal of Molecular Biology 41, 459-472.
Brewin, F. J., Dejong, T. M., Phillips, D. A. \& Johnston, A. W. B. (1980). Co-transfer of determinants for hydrogenase activity and nodulation ability in Rhizobium leguminosarum. Nature, London 288, 77-79.

Cantrell, M. A., Hickok, R. E. \& Evans, H. J. (1982). Identification and characterisation of plasmids in hydrogen uptake positive and hydrogen uptake negative strains of Rhizobium. Archives of Microbiology 131, 102-106.

Cantrell, M. A., Haugland, R. A. \& Evans, H. J. (1983). Construction of a Rhizobium japonicum gene bank and use in isolation of a hydrogen uptake gene. Proceedings of the National Academy of Sciences of the United States of America 80, 181-185.

Chen, T. S. \& Blanchard, D. K. (1984). Purification and properties of the $\mathrm{H}_{2}$ uptake hydrogenase of the $\mathrm{N}_{2}$-fixing anaerobe Clostridium pasteurianum W5. Biochemical and Biophysical Research Communications 122, 9-16.

FIGURSKI, D. \& HeLINSKI, D. (1979). Replication of an origin-containing derivative of plasmid RK2 dependent on a plasmid function provided in trans. 
Proceedings of the National Academy of Sciences of the United States of America 76, 1648-1652.

FrIEDRICH, C. G. \& FRIEDRICH, B. (1983). Regulation of hydrogenase formation is temperature sensitive and plasmid-coded in Alcaligenes eutrophus. Journal of Bacteriology 153, 176-181.

Haugland, R. A., Cantrell, M. A., Beaty, J. S., Hanus, J., Russell, S. A. \& Evans, H. J. (1984). Characterisation of Rhizobium japonicum hydrogen uptake genes. Journal of Bacteriology 159, 10061012.

JoNes, R., WoOdLey, P. \& RoBson, R. (1984). Cloning and organisation of some genes for nitrogen fixation from Azotobacter chroococcum and their expression in Klebsiella pneumoniae. Molecular and General Genetics 197, 318-327.

Klucas, R. V., Hanus, F. J., Russell, S. A. \& Evans, H. J. (1983). Nickel: a micronutrient element for hydrogen-dependent growth of Rhizobium japonicum and for expression of urease activity in soybean leaves. Proceedings of the National Academy of Sciences of the United States of America 80, 22532257.

LEE, S. B. \& Wilson, P. W. (1943). Hydrogenase and nitrogenase in Azotobacter. Journal of Biological Chemistry 151, 377-385.

Maier, R. J. \& Mutaftschiev, S. (1982). Reconstitution of $\mathrm{H}_{2}$ oxidising activity from $\mathrm{H}_{2}$ uptake negative mutants of Rhizobium japonicum bacteroids. Journal of Biological Chemistry 257, 2092-2096.

Maier, R. J., Campbell, N. E. R., Simpson, F. B., Russell, S. A. \& Evans, H. J. (1978). Expression of hydrogenase activity in free-living Rhizobium japonicum. Proceedings of the National Academy of Sciences of the United States of America 75, 3258-3262.

Maier, R. J., Hanus, F. J. \& Evans, H. J. (1979). Regulation of hydrogenase in Rhizobium japonicum. Journal of Bacteriology 137, 824-829.
Newton, J. W., Wilson, P. W. \& Burris, R. H. (1953). Direct demonstration of ammonia as an intermediate in nitrogen fixation by Azotobacter. Journal of Biological Chemistry 204, 445-451.

Partridge, C. D. P. \& Yates, M. G. (1982). Effect of chelating agents on hydrogenase in Azotobacter chroococcum. Evidence that nickel is required for hydrogenase synthesis. Biochemical Journal 204, 339344.

Partridge, C. D. P., Walker, C. C., Yates, M. G. \& Postgate, J. R. (1980). The relationship between hydrogenase and nitrogenase in Azotobacter chroococcum: effect of nitrogen sources on hydrogenase activity. Journal of General Microbiology 119, 313319.

Pedrosa, F. O., Stephan, M., Dobereiner, J. \& YATES, M. G. (1982). Hydrogen-uptake hydrogenase activity in nitrogen-fixing Azospirillum brasilense. Journal of General Microbiology 128, 161-166.

Robson, R. L., Chesshyre, J., Wheeler, K., Jones, R., Woodley, P. \& Postgate, J. R. (1984). Genome size and complexity in Azotobacter chroococcum. Journal of General Microbiology 130, 1603-1612.

SchinK, B. \& Schlegel, H. G. (1978). Mutants of Alcaligenes eutrophus defective in autotrophic metabolism. Archives of Microbiology 117, 123-129.

VAN DER WeRf, A. N. \& Yates, M. G. (1978). Hydrogenase from nitrogen fixing Azotobacter chroococcum. In Hydrogenases: their Catalytic Activity, Structure and Function, pp. 307-326. Edited by H. G. Schlegel \& K. Schneider. Gottingen: Erich Goltze.

YATES, M. G. \& WALKER, C. C. (1980). Hydrogenase activity and hydrogen evolution by nitrogenase in nitrogen fixing Azotobacter chroococcum. In Nitrogen Fixation, vol. 1, pp. 95-109. Edited by W. E. Newton \& W. H. Orme-Johnson. Baltimore: University Park Press. 